\title{
PERPEKTIF PENDIDIKAN TENTANG PERKEMBANGA PSIKOLOGI
}

\begin{tabular}{|c|c|}
\hline \multicolumn{2}{|r|}{ ANAK } \\
\hline Prodi Pendidikan Agam & $\begin{array}{l}\text { Pradana Anis Riantori } \\
\text { lam, Fakultas Agama Islam, Universitas Nahdlatul Ulama } \\
\text { Indonesia } \\
\text { E-mail: Pradana@gmail.com }\end{array}$ \\
\hline 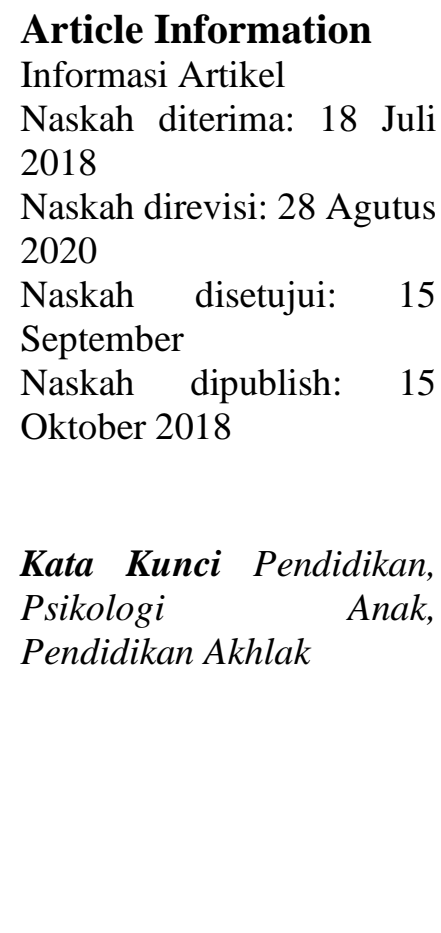 & $\begin{array}{l}\text { Abstak } \\
\text { Dalam konteks kehidupan berbangsa, pembinaan dan } \\
\text { pengembangan akhlak sangat penting, disaat sebagai berbangsa } \\
\text { indonesia tengah diuji dengan krisis multidimensional. Krisis } \\
\text { tersebut secara hakiki dipicu oleh adanya krisis akhlak (moral). } \\
\text { Dekadensi akhlak terjadi karena kita bangsa, sudah tidak } \\
\text { memagang teguh nilai-nilai akhlak yang selama ini kita pegang } \\
\text { secara kuat. Kebanyakan dari contoh dekadensi moral ini terjadi } \\
\text { pada anak menginjak usia remaja. Oleh karena itu pendidikan } \\
\text { harus dilakukan dalam rangka membentuk kepribadian yang } \\
\text { utama sesuai dengan kaidah-kaidah islam, terutama pendidikan } \\
\text { akhlak, harus ditanamkan sedini mungkin. Penelitian ini } \\
\text { bertujuan untuk mengetahui bagaimana Pendidikan Akhlak } \\
\text { pada Anak Usia Dini di Keluarga Karir di RW 03 Kelurahan } \\
\text { Sukabungah Kecamatan Sukajadi yang dirumuskan pada empat } \\
\text { pertanyaan yaitu bagaimana pelaksanaan, metode, materi dan } \\
\text { hambatan pendidikan akhlak pada anak usia dini di keluarga } \\
\text { karir. Berdasarkan hasil penelitian, dapat digambarkan adanya } \\
\text { usaha orangtua dalam menerapkan pendidikan akhlak pada } \\
\text { anak usia dini di keluarga walaupun, di tengah-tengah } \\
\text { kesibukan orangtua yang sama- sama bekerja. }\end{array}$ \\
\hline
\end{tabular}

\section{PENDAHULUAN}

Remaja merupakan aset penting dalam Islam.Sejarah mencatatkan bahwa kegemilangan Islam bermula dari tangan generasi muda yang memperjuangkan agama yang dibawakan oleh Baginda Nabi Muhammad SAW ini. Oleh karena itu seharusnya remaja ini dididik, dibimbing, dan diasuh dari kecil dengan pendidikan yang tersusun rapi untuk melahirkan generasi rabbani.Ide Imam al-Ghazali diguna-pakai dalam kajian ini karena beliau banyak mengutarakan pandangan tentang konsep akhlak dan pendidikan akhlak manusia. Bagi beliau, kaedah pendidikan akhlak manusia haruslah bermula dari pada peringkat bayi dan seterusnya berkembang hingga ke peringkat 
remaja, dewasa, dan lanjut usia (Fahmy Zarkasyi, 1990; dan Suhid, 2009) ${ }^{1}$.

Kaedah pembangunan akhlak remaja menurut Imam al- Ghazali pula meletakkan lima faktor yang boleh mempengaruhi pembangunan akhlak seseorang, yaitu: (1) Tazkiyyah al-Nafs atau pembersihan jiwa; (2) Mujahadah atau melawan hawa nafsu; (3) Melazimi amalan kebaikan; (4) membuat sesuatu yang bertentangan dengan akhlak yang buruk; dan (5) Muraqabatullah atau pengawasan diri terhadap Allah SWT (alGhazali, 2003:10) $)^{2}$

Dalam konteks kehidupan berbangsa, pembinaan dan pengembangan akhlak sangat penting, disaat sebagai berbangsa indonesia tengah diuji dengan krisis multidimensional. Krisis tersebut secara hakiki dipicu oleh adanya krisis akhlak (moral). Dekadensi akhlak terjadi karena kita bangsa, sudah tidak memagang teguh nilai-nilai akhlak yang selama ini kita pegang secara kuat. Kebanyakan dari contoh dekadensi moral ini terjadi pada anak menginjak usia remaja. Oleh karena itu pendidikan harus dilakukan dalam rangka membentuk kepribadian yang utama sesuai dengan kaidah-kaidah islam, terutama pendidikan akhlak, harus ditanamkan sedini mungkin. Penelitian ini bertujuan untuk mengetahui bagaimana Pendidikan Akhlak pada Anak Usia Dini di Keluarga Karir di RW 03 Kelurahan Sukabungah Kecamatan Sukajadi yang dirumuskan pada empat pertanyaan yaitu bagaimana pelaksanaan, metode, materi dan hambatan pendidikan akhlak pada anak usia dini di keluarga karir. Berdasarkan hasil penelitian, dapat digambarkan adanya usaha orangtua dalam menerapkan pendidikan akhlak pada anak usia dini di keluarga walaupun, di tengahtengah kesibukan orangtua yang sama- sama bekerja. ${ }^{3}$

Dalam kasus diatas ada kaitannya dengan pendapat Úsep Supriatna: bahwa dalam psikologi perkembangan, masa remaja (remaja awal dan remaja akhir) adalah masa yang penuh emosi, secara psikologis, masa ini ditandai dengan kondisi jiwa yang lebih, tidak menentu dan biasanya susah mengendalikan diri sehingga pengaruhpengaruh negatif seperti perilaklu-perilaku menyimpang akibat dari pergeseran nilai mudah mempengaruhi jiwa remaja dan menimbulkan gejala baru berupa krisis akhlak.

\footnotetext{
${ }^{1}$ Fahmi Zarkasyi, Hamid. (1990). Pemikiran Al-Ghazali tentang Pendidikan. Kuala Lumpur: Dewan Bahasa dan Pustaka. Suhid, Asmawati. (2009). Pendidikan Akhlak dan Adab Islam: Konsep dan Amalan. Kuala Lumpur: Utusan Publications dan Distribution, cet ke- 1.

${ }^{2}$ Imam al-Ghazali (2003:10)

${ }^{3}$ Hanifah.Portal Jurnal UPI.Tarbawi, Pendidikan Akhlak Pada anak Usia Dini di Keluarga Karir, 2011.
} 
Krisis akhlak yang melanda sebagian remaja saat ini merupakan salah satu akibat dari perkembangan global dan kemajuan IPTEK yang tidak diimbangi dengan kemajuan moral akhlak.Perilaku yang cenderung lekas marah, kurang hormat terhadap orangtua, bersikap kasar, kurang disiplin dan beribadah, menjadi pemakai obat-obatan terjerumus dalam perilaku bebas serta perilaku yang menyimpang lainnya telah melanda sebagian besar kalangan remaja.Keluarga (terutama orangtua) sebagai orang terdekat merupakan faktor utama untuk membantu para remaja dalam menghadapi krisis akhlak sebagaimana yang dikemukakan diatas.Pendidikan akhlak berupa bimbingan, arahan, nasehat, disiplin yang berlandaskan nilai-nilai ajaran agama Islam harus senantiasa ditanamkan dan dikembangkan orangtua terhadap para remaja dalam kehidupan keluarga ${ }^{4}$.

Mengasuh anak itu tidak semudah yang dibayangkan, walaupun anak-anak itu terlahir dari darah daging sendiri, tapi setiap anak punya karakter yang berbeda-beda. Sekali salah mendidiknya, seumur hidup orangtua akan menanggung akibatnya.

Mendidik anak bukanlah perkara sederhana, bila terjadi kesalahan dalam mendidik anak akan berakibat fatal dan berpengaruh terhadap perkembangan psikologi kognitif, afektif dan psikomotorik. Karena anak bukanlah barang maupun jasa bila rusak bisa diperbaiki, tentulah harus berhati-hati dalam mendidik anak, apalagi terhadap pendidikan akhlaknya.

Pendidikan agama sangatlah penting diberikan pada anak mungkin pendidikan agama harus yang pertama diberikan kepada anak sebelum pengetehuan lainnya, Sehingga anak kita mempunyai pegangan dalam mengambil langkah apapun sehingga tidak salah jalan.Berikanlah pendidikan agama sedini mungkin.

Ada beberapa cara dalam meningkatkan peran orangtua terhadap pendidikan anak anaknya.

1. Dengan mengontrol waktu belajar, waktu bermain sehingaa terbiasa mendisiplinkan waktu, jadi si anak terbiasa dan tau kapan waktu belajar dan kapan waktu bermain;

2. Memantau perkembangan kemampuan akademik disekolah dengan cara

\footnotetext{
${ }^{4}$ Ejournal.unirow.ac.id>home>2009>supriatna. (jurnal Usep Supriatna. Peranan Pendidikan dikeluarga dalam membina Akhlak Remaja. Nomor 2, oktober 2009. Prospektus tahun VII.
} 
memeriksa nilai nilai ulangan dan tugas dari sekolah;

3. Mengontrol kepribadian anak kita di luar rumah misal di sekolah dengan cara berkomunikasi dengan wali kelas mereka.

Disamping itu pengaruh terhadap anak memiliki corak yang berbeda pula kebanyakan anak-anak sangat sedikit menempuh jenjang pendidikan di karenakan membantu orangtua. Untuk menempuh jenjang pendidikan yang lebih tinggi dipegaruhi oleh ekonomi dan juga kesadaran orangtua terhadap kelanjutan pendidikan anakanaknya yang mengakibatkan pendidikan anak tidak terjaga dengan baik.

Oleh karena kurang kontrol dari orangtua yang berakibat rasa kebebasan bagi anak sangatlah tinggi baik dari segi tingkahlaku yang mengarah ke positif seperti pengajian, organisasi kemasyarakatan, namun yang lebih mendominani mereka yang kurang dikontrol adalah perilaku yang mengarah kepada hal-hal yang negatif seperti minum- minuman keras, tawuran, bahkan nonton film porno dari VCD ataupun HP.

Tetapi para koruptor mereka berpendidikan tinggi bahkan ada pula yang pendidikan akhlaknya baik, tapi mengapa mereka melakukan perbuatan keji seperti itu? Apakah karna orang tua salah mendidik anaknya atau karena mereka merasa lebih pintar makanya mereka dengan seenaknya melakukan hal yang dilarang oleh agama? Berarti disini pengaruh orangtua sangatlah penting untuk memberikan pendidik akhlak untuk merubah sikap seorang anak, agar seorang anak menjadi jauh lebih baik dan mengetahui sikap mana yang baik dan sikap mana yang kurang baik.

\section{PEMBAHASAN}

Hakikatnya khulk (budi pekerti) atau akhlak ialah suatu kondisi atau sifat yang telah meresap dalam jiwa dan menjadi kepribadian hingga dari situ timbullah berbagai macam perbuatan dengan cara spontan dan mudah tanpa dibuat-buat dan tanpa memerlukan pemikiran. Apabila dari kondisi timbul kelakuan yang baik dan terpuji menurut pandangan syari'at dan akal pikiran, maka ia dinamakan budi pekerti mulia dan sebaliknya apabila yang lahir kelakuan yang buruk, maka disebutlah budi pekerti yang tercela. Menurut penulis akhlak ialah suatu karakter atau sifat yang ada sejak lahir yang telah meresap kedalam jiwa dan menjadikan kepribadian baik atau buruk seseorang.

Dari pengertian di atas dapat diketahui bahwa akhlak ialah sifat-sifat yang 
dibawa manusia sejak lahir yang tertanam dalam jiwanya dan selalu ada padanya.Sifat itu dapat lahir berupa perbuatan baik, disebut akhlak yang mulia, atau perbuatan buruk, disebut akhlak yang tercela sesuai dengan pembinaannya ${ }^{5}$.

Ada dua penggolongan akhlak secara garis besar, yaitu akhlak mahmudah (fadhilah) dan akhlak madzmumah (qabihah). Di samping istilah tersebut Imam AlGhazali menggunakan istilah munjiyat untuk akhlak mahmudah dan muhlihat untuk yang madzmumah. Di kalangan ahli tasawuf dikenal system pembinaan mental, dengan istilah takhalli, tahalli, dan tajalli.

Takhalli ialah menggosongkan atau membersihkan jiwa dari sifat-sifat tercela, karena sifat itulah yang dapat mengotori jiwa manusia. Tahalli adalah mengisi jiwa dengan sifat-sifat terpuji (mahmudah). Jadi, dalam rangka pembinaan mental, penyucian jiwa hingga dapat berada dekat dengan Tuhan, maka pertama kali yang dilakukan adalah pembersihan jiwa dari sifat-sifat yang tercela, setelah itu, jiwa yang bersih diisi dengan sifat-sifat yang terpuji, hinggga akhirnya sampailah pada tingkat yang berikutnya yang disebut tajalli, yaitu tersingkapnya tabir sehingga diperoleh pancaran Nur Ilahi. Akhlak mahmudah ialah segala macam sikap dan tingkah laku yang baik.Akhlak madzmumah ialah segala macam sikap dan tingkah laku tercela.Akhlak mahmudah dilahirkan oleh sifat-sifat mahmudah yang terpendam dalam jiwa manusia, demikian pula akhlak madzmumah dilahirkan oleh sifat-sifat madzmumah. Oleh karena itu sifat dan tingkah laku yang lahir merupakan cermin atau gambaran dari sifat batin ${ }^{6}$.

Adapun sifat-sifat mahmudah itu adalah:

al-amanah (setia, jujur, dapat dipercaya); as-sidqu (benar, jujur); al- 'adl (adil); al'afwu (pemaaf); al-alifah (disenangi); al-wafa' (menepati janji); al-haya' (malu); arrifqu (lemah lembut); anisatun(bermuka manis).

Adapun sifat-sifat madzmumah adalah sebagai berikut: ananiah (egoitis); al-baghyu (melacur); al-bukhlu (Bakhil, kikir); al-buhta (dusta); alkhianah (khianat); al-zulmu (aniaya); al-ghibah (mengumpat); al-hasad (dengki); alkufran (mengingkari nikmat); ar-riya' (ingin dipuji); an-namimah (adu domba).

\footnotetext{
${ }^{5}$ Asmaran AS, Pengantar Studi Akhlak, (Jakarta : Raja Grafindo Persada, 2002), hlm. 1.

${ }^{6}$ A. Mustofa, op. cit, hlm. 197-199.
} 
Akhlak yang baik ialah segala tingkah laku yang terpuji (mahmudah) bisa dinamakan fadhilah (kelebihan). Akhlak Al-karimah atau akhlak yang mulia sangat amat jumlahnya, namun dilihat dari segi hubungan manusia dengan Tuhan dan manusia dengan manusia, akhlak yang mulia itu dibagi menjadi tiga bagian, yaitu:

\section{Akhlak Terhadap Allah}

Akhlak terhadap Allah adalah pengakuan dan kesadaran bahwa tiada Tuhan selain Allah.Dia memiliki sifat-sifat terpuji demikian Agung sifat itu, yang jangankan manusia, malaikatpun tidak akan menjangkau hakekatnya.

\section{Akhlak terhadap Diri Sendiri}

Akhlak yang baik terhadap diri sendiri dapat diartikan menghargai, menghormati, menyayangi dan menjaga diri sendiri dengan sebaik-baiknya, karena sadar bahwa dirinya itu sebgai ciptaan dan amanah Allah yang harus dipertanggungjawabkan dengan sebaik- baiknya. Contohnya: Menghindari minuman yang beralkohol, menjaga kesucian jiwa, hidup sederhana serta jujur dan hindarkan perbuatan yang tercela.

\section{Akhlak terhadap sesama manusia}

Manusia adalah makhluk social yang kelanjutan eksistensinya secara fungsional dan optimal banyak bergantung pada orang lain, untuk itu, ia perlu bekerjasama dan saling tolong-menolong dengan orang lain. Islam menganjurkan berakhlak yang baik kepada saudara, Karena ia berjasa dalam ikut serta mendewasaan kita, dan merupakan orang yang paling dekat dengan kita. Caranya dapat dilakukan denga memuliakannya, memberikan bantuan, pertolongan dan menghargainya ${ }^{7}$.

Jadi, manusia menyaksikan dan menyadari bahwa Allah telah mengaruniakan kepadanya keutamaan yang tidak dapat terbilang dan karunia kenikmatan yang tidak bisa dihitung banyaknya, semua itu perlu disyukurinya dengan berupa berzikir dengan hatinya.Sebaiknya dalm kehidupannya senantiasa berlaku hidup sopan dan santun menjaga jiwanya agar selalu bersih, dapt tyerhindar dari perbuatan dosa, maksiat, sebab jiwa adalah yang terpenting dan pertama yang harus dijaga dan dipelihara dari hal-hal yang dapat mengotori dan merusaknya. Karena manusia adalah makhluk sosial maka

\footnotetext{
${ }^{7}$ Prof. Dr. H. Moh. Ardani, Akhlak Tasawuf, ( PT. Mitra Cahaya Utama, 2005), Cet ke-2, hlm.49-57
} 
ia perlu menciptakan suasana yang baik, satu dengan yang lainnya saling berakhlak yang baik.

Akhlak Al-mazmumah (akhlak yang tercela) adalah sebagai lawan atau kebalikan dari akhlak yang baik seagaimana tersebut di atas.Dalam ajaran Islam tetap membicarakan secara terperinci dengan tujuan agar dapat dipahami dengan benar, dan dapat diketahui cara-cara menjauhinya.

Berdasarkan petunjuk ajaran Islam dijumpai berbagai macam akhlak yang tercela, di antaranya:

1. Berbohong Ialah memberikan atau menyampaikan informasi yang tidak sesuai dengan yang sebenarnya.

2. Takabur (sombong) Ialah merasa atau mengaku dirinya besar, tinggi, mulia, melebihi orang lain. Pendek kata merasa dirinya lebih hebat.

3. Dengki Ialah rasa atau sikap tidak senang atas kenikmatan yang diperoleh orang lain.

4. Bakhil atau kikir Ialah sukar baginya mengurangi sebagian dari apa yang dimilikinya itu untuk orang lain ${ }^{8}$.

Sebagaimana diuraikan di atas maka akhlak dalam wujud pengamalannya di bedakan menjadi dua: akhlak terpuji dan akhlak yang tercela. Jika sesuai dengan perintah Allah dan rasul-Nya yang kemudian melahirkan perbuatan yang baik, maka itulah yang dinamakan akhlak yang terpuji, sedangkan jika ia sesuai dengan apa yang dilarang oleh Allah dan rasul- Nya dan melahirkan perbuatan-perbuatan yang buruk, maka itulah yang dinamakan akhlak yang tercela. Tujuan disyariatkannya akhlak adalah agar setiap orang berbudi pekerti (berakhlak), bertingkah laku (tabiat), berperangai atau beradat istiadat yang baik yang sesuai dengan ajaran Islam? ${ }^{9}$

Menurut Oemar Muhammad at-Taumy asy-Syaibani; tujuan akhlak adalah kebahagiaan dunia dan akhirat, kesempurnaan jiwa bagi individu dan menciptakan kebahagiaan, kemajuan, kekuatan dan keteguhan bagi masyarakat ${ }^{10}$.

Tujuan dari pendidikan akhlak dalam Islam adalah untuk membentuk manusia

\footnotetext{
${ }^{8}$ bid, hlm. 57-59.

${ }^{9}$ Erwati Aziz, Prinsip-prinsip Pendidikan Islam,(Solo: PT. Tiga Serangkai Mandiri, 2003), hlm. 101.

10 Omar Mohammad al-Toumy al-Syaibany, Falsafah Pendidikan Islam,terj. Hasan Langgulung, (Jakarta: Bulan Bintang, 1979), hlm. 46.
}

Vol. 4 No. 2 Oktober $2018 \quad$ Halaman $107-132$ 
yang bermoral baik, keras kemauan, sopan dalam berbicara dan perbuatan, mulia dalam tingkah laku perangai, bersifat bijaksana, sempurna, sopan dan beradab, ikhlas, jujur dan suci. Dengan kata lain pendidikan akhlak bertujuan untuk melahirkan manusia yang memiliki keutamaan (al-fadhilah). Berdasarkan tujuan ini, maka setiap saat, keadaan, pelajaran, aktifitas, merupakan sarana pendidikan akhlak.Dan setiap pendidik harus memelihara akhlak dan memperhatikan akhlak di atas segala-galanya ${ }^{11}$.

Barmawie Umary dalam bukunya materi akhlak menyebutkan bahwa; tujuan berakhlak adalah hubungan umat Islam dengan Allah SWT dan sesama makhluk selalu terpelihara dengan baik dan harmonis ${ }^{12}$. Sedangkan Omar M. M.Al-Toumy Alsyaibany; tujuan akhlak adalah menciptakan kebahagian dunia dan akhirat, kesempurnaan bagi individu dan menciptakan kebahagian, kemajuan, kekuataan dan keteguhan bagi masyarakat ${ }^{13}$.

Dari pendapat di atas dapat disimpulkan bahwa tujuan akhlak pada prisnsipnya adalah untuk mencapai kebahagian dan keharmonisan dalam berhubungan dengan Allah SWT, di samping berhubungan dengan sesama makhlukdan juga alam sekitar, hendak menciptakan manusia sebagai makhluk yang tinggi dan sempurna serta lebih dari makhluk lainnya.

Pendidikan agama berkaitan erat dengan pendidikan akhlak, tidak berlebihan apabila dikatakan bahwa pendidikan akhlak dalam pengertian Islam adalah bagian yang tidak dapat dipisahkan dari pendidikan agama. Sebab yang baik adalah yang dianggap baik oleh agama dan yang buruk adalah apa yang dianggap buruk oleh agama. Sehingga nilai-nilai akhlak, keutamaan akhlak dalam masyarakat Islam adalah akhlak dan keutamaan yang diajarkan oleh agama.

Anak yang mulai menginjak remaja dalam perkembangan dan tingkahlakunya dipengaruhi oleh faktor dari dalam diri anak dan faktor dari luar.Salah satu faktor dari luar yang dapat mempengaruhi akhlak remaja adalah lingkungan keluarga terutama kedua orang tua. Sebagaimana Hadis Nabi Muhammad Saw, yang Artinya:

Dari Abi Hurairah r.a, Ia berkata, Rasulullah Saw bersabda, "Setiap anak

\footnotetext{
${ }^{11}$ Prof. DR. H. Ramayulis, Ilmu Pendidikan Islam, h. 115

${ }^{12}$ Drs. Barnawie Umary, $\quad$ Materi Akhlak, (Solo: CV Ramadhani, 1988). h 2

${ }^{13}$ Omar M. M.Al-Toumy Al-syaibany, Filsafat Pendidikan Islam, (Jakarta:Bulan Bintang, 1979), Cet ke-2, h.346
} 
dilahirkan dalam keadaan fitrah,maka kedua orang tuanya yang menjadikannya Yahudi, Nasrani atau Majusi”. (H.R. Al-Bukhari) ${ }^{14}$.

Dalam lingkungan keluarga, orang tua yang paling bertanggung jawab terhadap perkembangan anak, baik jasmani maupun rohani. Proses pendidikan ini sebenarnya dapat dilakukan dengan mudah, karena pada dasarnya (secara psikologi) seoranganak akan meniru dan meneladani orang tuanya. Dengan teladan ini timbullah gejala identifikasi positif, yaitu penyamaan diri dengan orang yang akan ditiru. Identifikasi positif itu penting sekali dalam pembentukan pribadi dan akhlak anak $^{15}$.Proses peniruan ini berlangsung tidak hanya ketika anak masih kecil, hingga anak menginjak remajapun proses peniruan ini tetap berlangsung ${ }^{16}$.

Proses peniruan terhadap orang tua ini tidak saja pada hal-hal yang baik saja, tetapi juga pada hal-hal yang buruk. Bahkan dalam al-Quran banyak sekali ayat yang menceritakan tentang peniruan (taqlid)terhadap orang tua atau nenek moyang yang itu adalah hal-hal yang buruk, seperti dalam surat al- Maidah ayat 104, yang berbunyi:

Artinya :Apabila dikatakan kepada mereka: "Marilah mengikuti apa yang diturunkan Allah dan mengikuti Rasul”. Mereka menjawab: “Cukuplah untuk kami apa yang kami dapati bapak-bapak kami mengerjakannya". Dan apakah mereka akan mengikuti juga nenek moyang mereka walaupun nenek moyang mereka itu tidak mengetahui apa-apa dan tidak (pula) mendapat petunjuk?. (QS. al- Maidah:104).

Keluaraga terutama orang tua adalah lingkungan pertama yang pertama kali ditemui oleh anak ketika ia dilahirkan. Lingkungan pertama harus diusahakan sebaikbaiknya sebagai lingkungan yang meguntungkan dan lingkungan yang optimal bagi perkembangan kepribadian yang baik. Keluarga dan suasana hidupnya, sangat berpengaruh atas taraf- taraf pemulaan perkembangan anak dan banyak menentukan sifat dan sikap apa yang akan terbentuk.

Bila lingkungan hidup sang anak bertambah luas, akan lebih banyak sosok yang menjadi objek peniruan dalam rangka pengisian hati nurani. Oleh karena itu orang tua

14 38 Al-Imam Abu Abdillah Muhammad bin Ismail al-Bukhari, Shahih al-Bukhari,Juz.I, (Beirut: Dar alKutub al-Ilmiyah, t.th.), hlm. 413.

${ }^{15}$ Ahmad D. Marimba, Pengantar Filasafat Pendidikan Islam,(Bandung:

PT. Al-Ma'arif, 1980), hlm.85

${ }^{16}$ Syamsu Yusuf, Op.Cit hlm.72.

Vol. 4 No. 2 Oktober $2018 \quad$ Halaman $107-132$ 
sangat berpengaruh dalam pertumbuhan, perkembangan dan pergaulan sang anak. Namun hal yang paling efektif adalah dengan cara mendidik anak dengan menggunakan pola didik dan pola asu yang sesuai ${ }^{17}$.

Perkembangan kognitif bukan hanya mempengaruhi pemahaman anak tentang dunia fisik, tetapi dunia social pula. Karena pemahaman peraturan moral dan social adalah penting dalam semua masyarakat, piaget tertarik kepada bagaimana anak menjadi memahami peraturan tersebut. Ia spektik bahwa pengaruh orang tua adalah kuat dalam perkembangan pemahaman tersebut seperti yang dinyatakan oleh teori saat ini. Namun ia menduga bahwa pemahaman anak tentang peraturan moral dan social harus menyesuaikan dengan tingkat perkembangan kognitif secara keseluruhan.

Yang menarik, Piaget mendasarkan teori awal di bidang ini pada observasi yang dilakukanya terhadap anak-anak berbagai usia yang bermain kelereng yang popular pada saat ini. Ia bertanya kepada anak-anak tersebut tentang asal mula, makna dan kepentingan peraturan permainan yang mereka ikuti. Dari jawaban mereka, ia merumuskan empat stadium perkembangan anak untuk memahami peraturan. Dua stadium pertama masuk ke dalam periode operasional yang kita diskusikan dalam bagian ini ${ }^{18}$.

Marah adalah sebuah bentuk emosi yang kuat. Mungkin Ibu akan merasa khawatir ketika melihat si Kecil menunjukkan emosi tersebut. Akan tetapi, Ibu harus ingat bahwa sebenarnya emosi semacam itu tergolong normal dan umum.Rasa marah berkaitan dengan banyak hal maupun emosi yang telah terpendam dalam kurun waktu tertentu.Bila dianalogikan, ini mirip sebuah gunung berapi. Tekanan dari berbagai hal yang terus-menerus bertumpuk di dalam menyebabkan anak tak mampu lagi membendungnya sehingga ketika rasa yang bercampur aduk kian menekan, ia akan meledak.

Memahami psikologi anak macam ini sangatlah penting, termasuk melihat penyebab kenapa si kecil sampai marah besar.

a. Kesedihan

\footnotetext{
17 id.slideshare.net/ViviLim11/2-33967784

${ }^{18}$ Piaget, 1932/1965.
} 
Terkadang kesedihan anak dapat ditumpahkan dalam bentuk kemarahan.Beberapa faktor yang mungkin membuat seorang anak bersedih adalah melihat pertengkaran orang tua, perceraian, kepergian seseorang yang sangat dekat, tidak memiliki teman bermain, suasana dan lingkungan baru, kurangnya perhatian orang tua, dan lain sebagainya.

b. Ketakutan

Anak bisa meluapkan ketakutannya dalam bentuk kemarahan.Beberapa hal yang menyebabkan ketakutan anak antara lain sakit, menjadi korban dari pelecehan fisik/seksual/emosi, dan lain sebagainya.

c. Frustrasi

Tak dapat dipungkiri, frustasi dapat menjadi sumber kemarahan karena psikologi anak yang tertekan.Hal-hal yang mungkin menjadi pemicu rasa ini adalah prestasi di sekolah yang tak kunjung mengalami peningkatan, tak mampu beradaptasi dengan suatu keadaaan atau lingkungan sekitar, memiliki cacat fisik, adanya kompetisi antar saudara, dan sebagainya.

d. Rasa bersalah

Secara psikologi, rasa bersalah dapat menyebabkan seorang anak marah. Beberapa hal yang mungkin membuat ia merasa bersalah antara lain merasa bertanggung jawab atas perceraian orang tua, kematian seseorang, menyakiti seseorang, dan lain sebagainnya.

e. Kekecewaan

Beberapa hal yang mungkin membuat seorang anak kecewa antara lain tidak diundang teman, tidak terpilih dalam suatu aktivitas bersama, tidak memenangkan suatu kompetisi, nilai yang tidak bagus, dan sebagainya.

f. Kekhawatiran

Secara psikologis hal yang dapat membuat seorang anak marah adalah rasa khawatir yang terus-menerus melanda.Rasa khawatir ini dapat disebabkan oleh kekhawatiran terhadap kondisi keluarga, kesehatan, kekerasan, kebimbangan, dan sebagainya.

g. Malu

Anak bisa saja merasa malu sehingga dia menjadi marah. Beberapa rasa malu 
yang mungkin membuat si Kecil marah adalah perasaan bahwa ia adalah orang paling bodoh, ketidakmampuan beradaptasi, dan sebagainya

h. Cemburu

Kecemburuan adalah kondisi psikologi anak yang mudah dideteksi. Ini biasanya terjadi apabila ia merasa kurang mendapat perhatian dibanding saudara atau teman .

Demikian beberapa hal yang dapat memicu kemarahan anak.Dengan mengetahui beberapa penyebab kemarahan tersebut, Ibu dapat menemukan solusi untuk mengatasi kondisi psikologi anak saat marah dengan lebih baik lagi.

Psikologi perkembangan adalah ilmu yang mempelajari tingkah laku individu dalam perkembangannya dan latar belakang yang mempengaruhinya.Dalam ruang lingkup psikologi, ilmu ini termasuk psikologi khusus, karena psikologi perkembangan mempelajari kekhususan dari pada tingkah laku individu ${ }^{19}$.

\section{KESIMPULAN}

Pertumbuhan dan perkembangan anak didik tergantung kepada otang tua apakah dia akan membentuk anaknya menjadi orang baik ataupun dia membiarkan anaknya menjadi orang yang tidak baik.

Menurut penulis peran orang tua sangat penting dalam pendidikan akhlak dan moral anak, karena jika kedua orang tuanya tidak baik maka seorang anak cenderung mengikuti sifat orang tuanya. Karena orang tua sangat berpengaruh dalam perkembangan psikologi kognitif anak. Dimana anak selalu meniru kebiasaan orang tuanya. Jadi, bagi penulis orang tua harus lebih berhati-hati dan ekstra dalam mendidik anaknya dalam bidang apapun terutama dalam bidang akhlak. Karena banyak orang tua yang sholeh dan sholehah tetapi mereka tidak mampu mendidik anak-anak mereka dengan baik sehingga, anak-anak mereka mempunya akhlak yang tidak baik, anak dengan seenaknya seks bebas,anak memakai narkoba dan memaki-maki orang tua, bahkan ada anak yang membunuh orang tuanya. "Naudzu billah". Tetapi ada orang tuanya kurang baik tetapi mereka sangat keras mendidik akhlak anaknya, dan anaknya pun sadar akan pentingnya akhlak. Maka anak yang seperti itulah menjadi anak yang sholehah dan anak yang dapat mengangkat derajat orangtuanya baik di dunia maupun di

${ }^{19}$ http://belajarpsikologi.com/pengertian-psikologi perkembangan/hari Jum'at tanggal 21 November 2014 Jam 19.30 . 
akhirat. Dan dapat mengingatkan kepada kedua orang tuanya.

\section{DAFTAR PUSTAKA}

Suhid, Asmawati. (2009). Pendidikan Akhlak dan Adab Islam: Konsep dan Amalan. Kuala Lumpur: Utusan Publications dan Distribution, cet ke-1.

sumsel.kemenag.go.id/file/file/BANYUASIN/pfyl1341 188835.pdf. hari senin 17

November 2014. Jam 10.30.

Suryabrata, Sumadi.,Metodologi Penelitian, Jakarta: Raja Grafindo Persada, 2003, cet.14.

Umary, Barnawie. Drs., Materi Akhlak, (Solo: Cv Ramadhani, 1988) hlm. 2.

Warwick, Donald P. And Lininger, Charles yang dikutip dari Masri Singarimbun dan Sofyan Effendi ( Metode Penelitian Survei).

Woodworth, R.S. and Marquis, D.G., Psychology, A Study of Mental Life, Methuen \& Co. Ltd., London.

Woolfson, Richard. C. 2004. Mengapa Anakku Begitu? Jakarta : Erlangga Kids.

Yunus, Abdaul Hamid, et.al.,Dairah al-Ma'arif, III, Dar al- Sya'b, Cairo, t.t. 
Strategi Aktif Untuk Meningkatkan Prestasi Belajar Pendidikan Agama Islam

Vol. 4 No. 2 Oktober 2018

Halaman 107 - 132 